\title{
Spiritual Intelligence of Islamic Education Concepts
}

\author{
Mohamad Erihadiana*, Supiana \\ Department of Islamic Education \\ UIN Sunan Gunung Djati \\ Bandung, Indonesia \\ *erihadiana@uinsgd.ac.id
}

\author{
Ahmad Hasan Ridwan \\ Department of Islamic Law \\ UIN Sunan Gunung Djati \\ Bandung, Indonesia
}

\begin{abstract}
Education should develop adequately all dimensions of human intelligences. One of the neglected intelligences is spiritual intelligence. Spiritual Intelligence (SQ) is a scientific finding, first conceived by Danah Zohar and Ian Marshall through very comprehensive research. Even though the SQ did not touch God at first, in Indonesia SQ was further interpreted as a transcendental relationship between humans and God. The purpose of this study is to explain and analyze the concept of Islamic Education about the development of Spiritual Intelligence (SQ) dimensions. The method used is a critical analytical method to the theory of spiritual intelligence in the perspective of Islamic Education. The concept of Islamic Education is known as the theory of tazkiyat al-nafs (purification of the soul). Tazkiyat al-nafs in Islamic Education can be seen from three perspectives, namely the perspective of the Qur'an, Al-Hadith, and Psychology. Spiritual Intelligence (SQ) in the concept of Islamic Education is tazkiyat al-nafs, namely efforts to spiritual purification, purify the soul, educate the mind, improve morals, and cleanse the body. All efforts are closely related to belief in Allah.
\end{abstract}

\section{Keywords—spiritual intelligence, islamic education}

\section{INTRODUCTION}

The issue of Intellectual Intelligence (IQ) as the only measure of human intelligence, has been believed by many people in the early twentieth century. However, Daniel Goleman [1], through various research results, shows that the Intelligence Quotient (IQ) is not the only measure of intelligence. There is another measure of intelligence known as Emotional Intelligence (EQ) which includes the ability to understand emotions, listen to other people and sympathize with their emotions, and the ability to express them productively [2].

In subsequent developments, IQ and EQ are considered insufficient to explain the overall complexity of human intelligence and also the richness of imagination [3]. The criticism of IQ and EQ gave birth to a new psychological theory of intelligence known as Spiritual Intelligence (SQ). SQ is deeply rooted in the human brain. This means that humans not only have the potential for rational and emotional strength, but also have spiritual potential in themselves or in their brains [4]. Marsha Sinetar and Khalil Khavari provide a definition that is considered more in accordance with the latest psychological developments, namely Spiritual Intelligence is a mind that gets inspiration, encouragement, and inspired effectiveness, the is-ness or the realization of divinity in which we all become part [5].

Referring to the opinion of Khavari [6] that Spiritual Intelligence is a faculty of the nonmaterial dimension of man, namely the spirit, then the previous Muslim scientists actually had a very big share in developing this study of spiritual intelligence through the study of the soul (al-nafs). Because in fact, the understanding of the nafs by the first generation of scholars was inspired by the Koran and al-Hadith. The word nafs is in the Koran and is referred to by the Koran by several terms, namely qalb (heart), 'aql (intellect), bashîrah (conscience), and rûh or spirit. Spiritual intelligence in the concept of Islam is known as the theory of tazkiyat al-nafs (purification the soul).

\section{Spiritual Intelligence The PersPective of Muslim SCIENTISTS}

Spiritual intelligence among Muslim scientists is not a new topic. The issue of spiritual intelligence has long been discussed by Muslim scholars from among the mufassirs, philosophers and Sufis. SQ is directly related to the spirit substance or spirit. The existence of the spirit in humans is a direct intervention by Allah SWT without involving other parties, as well as other creation processes. This can be understood through the verses of the al-Qur'an as follows:

"So when I have completed the incident, and have breathed into it my spirit (creation), then you submit to him by prostrate" (Surah Al-Hijr / 15: 29).

"So when I have completed the incident and I covered it with my spirit (creation); then you should fall down on your knees to him" (Surah Shad / 38: 72").

The presence of a spirit or a third element in a person enables him to access spiritual intelligence. However, the pursuit of intelligence is not the same for everyone. Certainly, a prophet or wali has more potential to get this intelligence, because he is given more specialties than other people. But that doesn't mean that ordinary people can't get this intelligence.

According to Umar [7], Al-Gazali [8] has actually introduced this spiritual intelligence model with several names, 
as can be seen in his mukasyafah and ma'rifah concepts. According to Al-Gazali, spiritual intelligence in the form of mukasyafah (direct expression) can be obtained after the spirit is freed from various obstacles. The Spirit is no longer veiled by illusions of the mind and the mind no longer closes the vision to reality. What is meant by obstacles here are worldly tendencies and various mental illnesses. This preamble is also the ultimate target of seekers of truth and those who wish to put their faith in above certainty. Absolute certainty about a truth is only possible at this level [7].

According to Al-Gazali, spiritual intelligence can be obtained in the heart through different circumstances, sometimes through inspiration which is only a "disclosure" (mukâsyafah) to a personal human being conveyed through his mind. But sometimes you have to think and learn. Intelligence acquired through effortless inspiration and research would not exist if there was an intermediary between man and his creator. Inspiration is likened to light falling upon a heart that is pure and true, clean, and gentle. Knowledge obtained directly from Allah SWT is what is called 'Ilm al-Ladunny [8].

Al-Gazali based his opinion based on Q.S. Al-Baqarah / 2: 269:

"Allah bestows al-hikmah (deep understanding of the Qur'an and Al-Sunnah) to whom He wills. And whoever is gifted with al-wisdom, he really has been awarded a lot of gifts. And only those who have wisdom can take lessons".

The first journey to achieve spiritual intelligence is tazkiyat al-nafs which is translated as purification of the soul. The tazkiyat al-nafs is referred to as sulûk nafs. This means adorning oneself with praiseworthy and malakuti (angelic qualities), after cleaning them from their despicable and animal traits. In other words, the self is cleaned of dirt and damage [9].

If intellectual intelligence is determined by reason, then Spiritual intelligence which is termed spiritual intelligence, which is determined and determined by Sufistic experience through cleansing efforts or tazkiyat nafs must also be followed by three conditions, namely: grateful and not complaining, alert and not careless, restraining and not being lulled by nafs [10].

Ibn Arabi further analyzed spiritual intelligence by relating it to the three characteristics of this science, namely holy knowledge ('ilm al-ladunni), science of mysteries ('ilm alasrar) and science of the occult ('ilm al-gaib). These three types of knowledge are inaccessible to intellectual intelligence. Regarding intellectual intelligence, Ibn 'Arabi tends to follow Al-Hallaj's opinion which states that human intellect is incapable of understanding realities. Only with spiritual intelligence can understand the three characteristics of knowledge mentioned above [7].

Al-Gazali and Ibn 'Arabi have close opinions about the accessibility of spiritual intelligence. According to Al-Gazali, if someone is able to synergize the various abilities and intelligences that exist in humans, then that person can "read" the universe. The ability to read the universe here is a rung to knowledge (ma'rifah) about His creator. Because the universe according to Al-Gazali is the "writing" of Allah SWT.

\section{RESEARCH METHODS}

The research method used is critical analytical method Therefore, a series of facts will be collected, grouped, and interpreted or analyzed to produce a theory. The critical analytical method is a method developed with the object of studying human ideas or ideas contained in print media [11].

The research technique used is literature study. Literature study techniques are used to obtain sufficient sources of study as an effort to obtain the concept of Islamic Education on Spiritual Intelligence.

\section{RESULTS AND DISCUSSION}

Spiritual intelligence obtained through tazkiyat al-nafs in the perspective of the Koran, in addition to the use of lafaz nafs which is used by the Koran to refer to humans as the totality of humans, including the activities of our minds, hearts and members of our bodies; includes faith and good deeds; and includes all of our obedience in carrying out Allah's law in total in all aspects of our lives.

In the perspective of the sunnah, tazkiyat al-nafs was also hinted at by the Prophet Muhammad. The word nafs in the sunnah often means in line with qalb, so the hadiths that mention the purity of qalb are the same as the purity of the nafs, and the term qalb disease is actually the same as the disease of the nafs [12]. This similarity, for example, is shown by the hadith narrated by Bukhari:

"... Indeed, in the human body there is a lump of flesh. If the meat is good, then the whole body is good. But if the flesh is bad, then the whole body is bad. Remember, that lump of meat is a heart.

Based on the analysis of the verses of the Koran, the narrations in al-Hadith, and the opinions of Muslim scholars, there are 4 stages of education to achieve spiritual intelligence: (1) tilâwah; (2) tazkiyah; (3) ta'lîm; and (4) wisdom. The process of tilâwah is an activity to understand this phenomenon of the universe. Students are brought to understand the environment as the creation of Allah Almighty. Operationally, it may take the form of language education, arithmetic, reading and writing, as well as other knowledge, from one stage to the next in a broader scope and area.

Educating must also be interpreted as purifying the heart, which is tazkiyah. In this context, students are guarded not to lie, consume food that is not halal, are introduced to how to be grateful, patient, sincere, and istiqamah. Furthermore, students are introduced to the holy book and also wisdom or wisdom. The tazkiyah process, the introduction of the Scriptures - let alone wisdom - is a realm that transcends the rational and positivistic levels.

Especially for soul purification (tazkiyat al-nafs) and soul education (ta'dîb al-nafs), it can be done in various ways and 
methods. The methods used are based on the sunnah of the Prophet Muhammad. of which are as follows.

\section{A. Tazkiyat al-Nafs through Penance}

The order to repent as ordered by the Prophet Muhammad. through his words in the hadith narrated by Muslims:

"O people repent to Allah, verily I repent to Allah no less than a hundred times a day."

"Whoever repents before the sun rises from the place where it has set, Allah will forgive his sins."

"Verily Allah 'Azza wa Jalla extends his power with forgiveness for those who sin at night until daytime and for those who sin from day to night until the sun rises from where it sets."

\section{B. Tazkiyat al-Nafs through Murâqabah}

Murâqabah is to feel the majesty of Allah Azza wa Jalla at all times and in all circumstances and to feel His togetherness in quiet or busy times [13]. The hadith narrated by the Prophet Bukhari states:

“.... Explain to me about ihsan, (Rasulullah Saw.) Replied: You worship Allah as if you see Him, if you don't see it, actually He sees you.

Believing that Allah SWT. always with him, He is AllHearing and All-seeing that is hidden even in the heart. The soul will be kept pure if muraqabah has been done so that morals will remain upright and righteous deeds will flourish.

\section{Tazkiyat al-Nafs through Muhâsabah}

The meaning of muhâsabah is self-introspection, muhâsabah is done after doing an act of deeds, what is the goal of the alma to get the pleasure of Allah? Or is his charity infused with riyâ 'nature? Has he fulfilled God's rights and human rights? [13].

Rasulullah Saw. said: From Anas r.a actually a man said to the Prophet: Advise me, O Allah's Apostle! So the Prophet SAW said: consider when you do something; If you think that the action is good then go ahead, but if you are worried that you will be misguided, stop it (Mushnaf Abd al-Razâq, Juz 11).

Regarding muhâsabah, in the hadith narrated by Tirmidhi, Umar ibn al-Khatab r.a said: From Umar ibn Khatab said: recite yourself before you are judged, weigh yourself before you are weighed, and get ready for a great performance (the Day of Judgment). Indeed, the reckoning on the Day of Judgment will be light for those who judge themselves while in the world.

The hadiths and sayings of Umar are in line with the word of Allah SWT. in the Koran:

"O you who believe, fear Allah and let each one pay attention to what he has done for the next day (hereafter); and fear Allah, Allah knows best what you are doing (Qs. al-Hashr / 59: 18)"

Muhâsabah is also concerned with remembering death and life after death. In the hadith narrated by Tirmidhi, Rasulullah Saw said:

"Expand to remember the destroyer of all pleasures, namely death".

In the hadith based on the history of Bukhari from Abdullah Ibn Umar r.a, it is stated that: From Abdullah Ibn Umar r.a said: Rasulullah Saw grabbed my shoulder and said: "Be you in this world like a stranger or just passing by". Then Ibn Umar said: "If you meet in the evening do not wait until morning comes. And if you meet in the morning don't wait for the afternoon to come. Use your healthy time to face sick time, and use your life for your death.

\section{Tazkiyat al-Nafs through Mujâhadah}

In the hadith narrated by Bukhari and Muslim, Rasulullah Saw. as qudwah provides examples of mujâhadah or optimization in worship and obedience to Allah SWT.

From Mughirah ibn Syu'bah, he said: Rasullah Saw stood up (for night prayers) until his legs were swollen, so I asked him: "Why do you burden yourself with things like this (night prayers) when Allah has forgiven your sins in the past. and sin to come? Rasulullah Saw. replied: "Can I not be a grateful servant."

Guidance of the Prophet Muhammad. Regarding the mujâhadah is also described through the hadith narrated by Imam Bukhari from Abu Hurairah:

"Indeed, Allah SWT. said that whoever makes me a protector, I will listen to him when it is difficult and not a servant of mine draws near to me with something that I prefer more than the obligatory deeds and a servant of mine always draws near to me by doing deeds circumcision, so that I love him. If I have loved him, then I will be his hearing, and as the hand he uses to hold and the foot he uses to walk, and when he pleads with Me I will certainly grant it, and if I take refuge in Me I will definitely protect it".

Tazkiyat al-nafs through optimization of obligatory worship and circumcision as described in the hadith also applies to tilâwah and tadabbur al-Quran. The remedy for liver disease, sorrow remover, and anxiety destroyer is to suppress reading the Koran. In Musnad Ahmad, Prophet SAW. teach the prayer as follows:

"O Allah, I am Your servant, the son of my father and mother who are also Your servants. My head is in Your hands, I am walking according to Your laws, moving in Your provisions. I ask You with all the names that belong to You, the names that You gave to yourself, or which You taught to one of Your creatures, or which You sent down in Your book, or which You have hidden in knowledge. unseen by Your side, make the Koran a garden of my heart, the light of my heart, and an eraser of sorrow, as well as a cure for my doubts. 
The concept of Islamic Education regarding the development of the dimensions of Spiritual Intelligence (SQ) is through tazkiyat al-nafs. Tazkiyat al-nafs in Islamic education has the following objectives:

1) It is this tazkiyah al-nafs (mental cleansing) that is most relevant to what is called counseling today

2) Tazkiyah al-aql (explanation of reason), this component contains two things:

- Tazkiyah al-aqâid (clarifying the faith)

- Tazkiyah Asâlib al-Tafkîr (clarification of ways of thinking) in students are trained to: (1) self-criticism (self critism); (2) conduct renewal not taqlid (innovation); (3) think scientifically and (5) think collectively.

3) Tazkiyah al-Jism (body cleansing)

- Compilation of body needs which aims for growth and physical health.

- and one's body at once.

\section{CONCLUSION}

The process of purifying the soul is referred to as tazkiyat al-nafs or al-Ghazali which refers to it as riyâdhat al-nafs. According to al-Ghazali, one of the functions of education is to promote Islam, maintain the sanctity of the soul, and taqarrub ilâ Allâh. Education is an effort to guide, improve, perfect, and purify the heart to be close to the Khaliq, namely Allah SWT. This thinking is based on the view that humans are noble creatures.

Human perfection lies in the purity of his heart. Al-Qur'an and Hadith are two heirlooms of the Prophet Muhammad. which every Muslim must always refer to in all aspects of life. One of the most important aspects of life is the formation and development of the Muslim personality.
There are three characteristics or characteristics that must be attached to the Muslim person as a result of tazkiyat al-nafs, namely: (1) salim al-aqîdah or clean aqidah; (2) Sahîh al'Ibâdah or true worship; and (3) Matîn al-Khuluq or strong morals.

To achieve this character, various tazkiyah methods are taken, including: prayer, fasting, zakat, pilgrimage, reading the Koran, zikr, meditating on God's creatures, remembering death (zikr al-maut), murâqabah, muhâsabah, mujâhadah, and mutâba'ah, jihâd amar ma'ruf and nahi munkar, khidmah and tawadhu, knowing the entry of Satan into the soul and blocking it, knowing heart disease and avoiding it.

\section{REFERENCES}

[1] D. Goleman, Emotional Intelligence: Why it Can Matter More Than IQ London: Bloomsbury, 1996.

[2] A. Efendi, 21st Century Intelligence Revolution. Bandung: Alfabeta, 2005.

[3] D. Zohar, I. Marshall, and I.N. Marshall, SQ: Connecting with our spiritual intelligence. Bloomsbury Publishing USA, 2000.

[4] T. Pasiak, IQ / EQ / SQ Revolution between Neuroscience and AlQuran. Bandung: Mizan, 2002.

[5] M. Sinetar, Spiritual Intelligence. New York: Orbis Books, 2000.

[6] K. Khavari, Spiritual Intelligence. Ontario: White Mountain Publication, 2000 .

[7] N. Umar, Spiritual Intelligence in the Koran. https://iccjakarta.com/2018/03/06/6136-2/.

[8] Al-Ghazali, Al-Risâlat Al-Laduniyah, Jakarta: Hikmah, 2003.

[9] M. Valiuddin, Contemplative Disciplines in Sufism. Bandung: Pustaka Hidayah, 1996.

[10] J. Nurbakhsy, 2001. Psychology of Sufism (Del wa Nafs). Yogyakarta: Fajar Pustaka Baru, 2001.

[11] M.D. Ridwan, New Traditions of Islamic Research. An interdisciplinary overview. Bandung: Nuansa, 1996.

[12] Said Hawwa, Tarbiyatunâ al-Rûhiyyah. Yogyakarta: Mitra Pustaka, 2006.

[13] A.N. Ulwan, Ruhâniyah al-Dâ'iyah. Jakarta: Rabbani Press, 1996. 